\title{
Hybrid Picking Applied to Classical Guitar
}

\author{
Técnica híbrida de palheta e dedos aplicada ao violão
}

\author{
Marcos Maia \\ Universidade Estadual do Ceará, Fortaleza, Ceará, Brazil \\ marcosmaiamusic@gmail.com
}

\section{Carlos Fiorini}

Universidade Estadual de Campinas, Campinas, São Paulo, Brazil

fiorini.carlos@gmail.com

\begin{abstract}
Hybrid picking refers to the practice of using the pick, held between the thumb and index fingers, in a combined action with right-hand medium, ring and pinky fingers. This enables the performance of rhythmicharmonic accompaniment, as well as polyphonic textures and melodic lines. This work presents the contextualization of this technique applied to classical guitar by discussing historical aspects and indicating musical examples of various genres and composers. For those guitarists who use the pick exclusively, hybrid picking allows the performance of a mostly varied repertoire.
\end{abstract}

Keywords: classical guitar technique; hybrid picking for guitar.

Resumo: Técnica híbrida de palheta e dedos refere-se à prática do uso da palheta, presa entre os dedos polegar e indicador, em ação combinada com os dedos médio, anular e mínimo da mão direita. Isso possibilita a execução de bases rítmico-harmônicas, bem como texturas polifônicas e linhas melódicas. Esse trabalho apresenta a contextualização dessa técnica aplicada ao violão, discorrendo sobre aspectos históricos e indicando exemplos musicais de variados gêneros e compositores. Para aqueles violonistas que usualmente se utilizam exclusivamente da palheta, a técnica híbrida permite a performance de um repertório mais diversificado.

Palavras-chave: violão clássico; técnica híbrida de palheta.

Submission date: 23 March 2017

Final approval date: 26 March 2018

\section{1 - Introduction}

Guitar, according to HENRIQUE (1988, p.147) is a musical instrument classified in the group of pinched string chordophones, although the same author also names it as a finger plucked chordophone. This instrument allows varied right-hand techniques including the use of fingers only, of picks, and of both.

Hybrid picking is an expression that refers to a peculiar right-hand guitar technique, in which there is a joint action of the pick, held between the thumb and index finger, combined with the use of middle, ring and little fingers (FORMADLEY, 2014, p.1).

Guitarists who usually perform with pick exclusively can play melodic lines, arpeggios, chord notes and rasgueados. However, polyphonic textures, contrapuntal and popular music genres, 
that require the simultaneous attack of chord notes, become impracticable. The technical features of using a pick, associated to the use of fingers to pluck the strings, as in hybrid picking, results in feasibility and diverse guitar performance possibilities, expanding the scope of varied repertoire. The development of hybrid picking technique involves the handling of the pick, the combination of pick and fingers, and notably the ability of using the right hand little finger.

\section{2 - Historical background}

\subsection{The use of plectrum and pick}

The use of the plectrum in plucked string instrument dates back to the times of ancient Greece. According to PUJOL (1960, p.40) "among the ancient Greeks, two distinct styles of striking the strings were favored, some players using the fingers, others a plectrum". For the same author, the writings of Plutarch, Athanaeus, Anacreon, Aristogenes and Virgil show some references regarding the use of ivory artifacts by Greek sitar players. There was a direct relationship between "striking the strings with an ivory plectrum and sing a merry melody in a loud ringing voice".

CAMPOS (2005, p.11) refers that with the arisen of Roman civilization and its historical domination over the ancient world, the sitar or Greek kithara was renamed Roman sitar, which was introduced in the Iberian Peninsula by the Romans in the first year of the Christian era. The same author says that when the Moors invaded Spain in the eighth century, the Arab lute or oud, and the Moorish guitar, both played with use of the plectrum, were introduced in Europe. HOOVER (1995, p.12) states, "feather quills, in fact, may have been the first standardized plectrums".

The plectrum differs from the pick in form and size. The first resembles a small ivory rod, with approximate average size of a human hand (Figure 1). The second features in a smaller size, which can range on average between two and four centimeters, in various shapes, colors, thicknesses and raw materials (Figure 2).

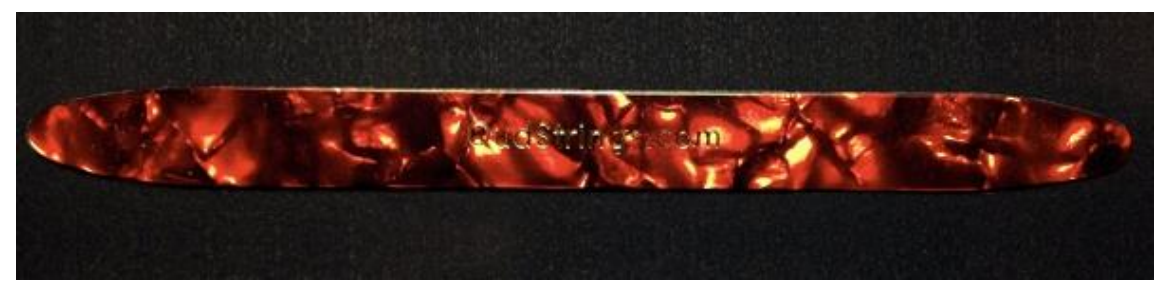

Figure 1: Celluloid plectrum (Source: Available in:

http://www.oudstrings.com/index.php?route=product/product\&product id=101. Accessed: March 22, 2017). 


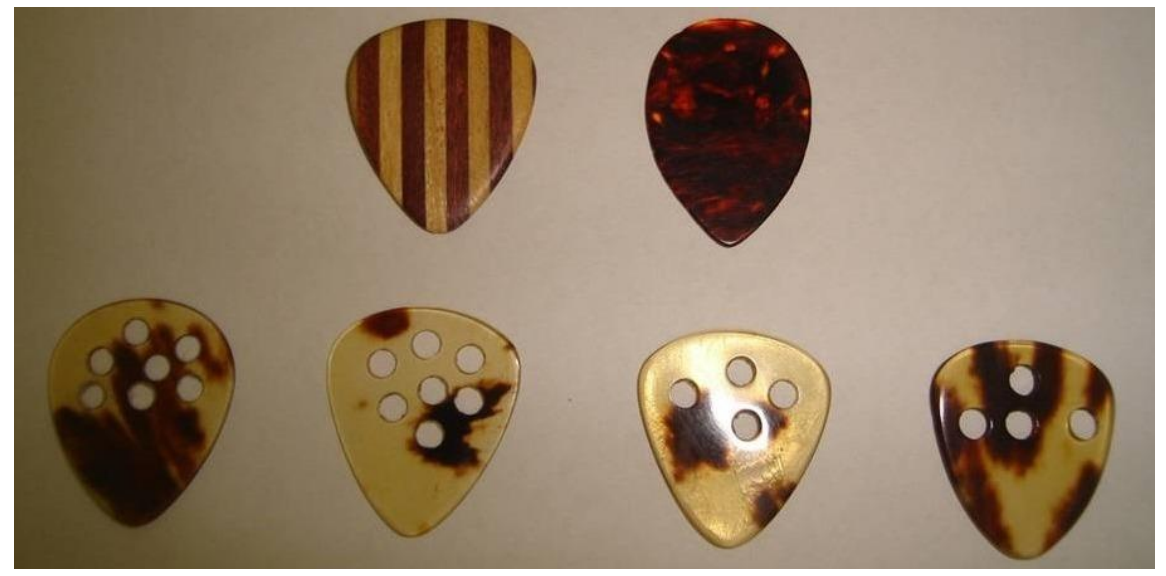

Figure 2: Different types of picks according to the raw materials used: wood, plastic and tortoise shell. (Source: Personal Archive).

BIGGI (1999, p.4) who studies medieval repertoire for the lute, said that the change from the use of plectrum to finger playing technique happened in the late fifteenth century: "(...) the universally accepted theory is that the musicians abandoned the little piece of feather which they had used until then, as soon as the polyphonic interpretation became necessary, in order to play with more fingers".

The musicologist Genevieve Thibauld, cited by BIGGI (1999, p.4), has glimpsed a period of transition between the two techniques stating, “(...) the transition from plectrum to finger playing was not an abrupt one, and the two techniques must have coexisted for a certain time". This historical moment represents the meeting of the two playing techniques. The use of the plectrum is restricted, nowadays to Arab lute players in Eastern culture, while the pick got popular in Western world, as from nineteenth century.

The guitar history in Europe does not show tangible evidence regarding the use of the pick in many music publications. From Renaissance to Modern period there was a predominance of finger playing. Only at the turn of the nineteenth and twentieth centuries emerged the first reports on the use of the pick in North America.

According to historian Alan Lomax in "The Folk Songs of North America", quoted by GRUNFELD (1969, p.248), "(...) negroes introduced the guitar and the blues into the hills some time after the turn of the century, (...) in fact (...) is still called nigger pickin." Also according to GRUNFELD (1969, p.258), in the 30s, Charlie Christian, a guitarist of American jazz Swing era, started playing an acoustic guitar and by 1937 he was introduced to the electric guitar, maintaining the use of the pick.

Other guitarists worth to be mentioned as pick technique users were Freddie Green and Django Reinhardt. The first, known for his rhythm style with downstroke picking in the Count Basie Orchestra, and, the late, known as the creator of European Gypsy Jazz. Thus, the pick enabled to obtain a rhythmic, harmonic and crisp stroke, contributing to a more competitive performance along with other instruments within jazz groups. 
Currently, many blues guitarists, jazz and rock ones still use the pick. This practice of American popular music and European jazz reflected also in Brazil. In this country, musicians who still use the pick are the mandolinists, cavaquinho players, and electric guitarists in harmonic accompaniment and melodic improvisations in various genres of popular music.

An association between pick and steel strings is usually referred; in the same way, that occurs with nylon strings and finger playing. "The plectrum (pick) is usually employed for instruments with metal strings; the gut or nylon strings are usually plucked with the fingers" (HORTA, 1985, p.294). But there are those who go against these paradigms, playing steel string instruments with the nails of the right hand fingers, and nylon strings with a pick.

\section{2 - The use of fingers}

Timbre preferences of Antiquity already envisioned the use of fingers, besides to the use of the plectrum, by Greek sitar players. Plutarch relates, “(...) the strings plucked with the fingers produced a much sweeter and pleasanter sound than the plectrum. (...) Aristogenes and Anacreon also considered the sound of strings plucked with the fingers better than that produced by the plectrum." (PUJOL, 1960, p.40).

At the Renaissance period, when polyphony was already well developed, music works composed for the Spanish guitar, vihuela and lute were, as a rule, played using the fingers. After the vihuela and the lute fell out of favor in Europe by the end of the eighteenth century, the guitar emerged as the preferred instrument.

The right hand guitar technique has been developed over five centuries, from the Renaissance to date. The guitarists assimilated many ways of playing the old instruments, in which the movement of the fingers often imitated the movements of the pick, as quoted, "(...) in Renaissance lute playing, the thumb imitated the down stroke of the plectrum and the index finger imitated the up stroke" (POSTLEWATE, 2001, p.7).

The guitar in the Baroque period gained a privileged position never gained before in early history of the instrument. There were two kinds of guitarists, those who produced pure musical art and those with the role of accompanying songs. The practice of accompaniment, also known as rasgueado and the solo practice (punteado) were both reunited by the musicians of that period. The baroque guitar was always oscillating between the two extremes as were referred. "(...) in this combination of rasgueado and punteado it achieved for the first time an identity of its own in the musical world" (TURNBULL, 1974, p.61).

From Classical period to present day, pedagogical methods and collections of guitar works published over the centuries in Europe, traditionally present the use of thumb (p), index finger (i), middle (m) and ring finger (a) as in PINTO (1978, p.15). In the nineteenth century arise the first attempts to add the use of the right hand fifth finger in the performance practice. "(...) the letter 'c' indicates the little finger (the pinky; chiquito in Spanish)" (TENNANT, 1995, p.44). 


\section{3 - The use of the little finger}

The development of the ability to use the right hand little finger is vital for those guitarists interested in applying hybrid picking. However, the use of the fifth finger generates much controversy among guitarists. According to POSTLEWATE $(2001, \mathrm{p} .7)$, the first reference to the subject in guitar history is in the guitar method called Escuela de Guitarra, published in 1825 by Dionisio Aguado (1781-1849). Aguado was the first guitarist to propose the use of all righthand fingers in arpeggios studies. For him, these five fingers could be used - one for each string, leaving the thumb to play the bass. The proposal to use the right hand little finger was abandoned and, only one century later, the Argentine guitarist Domingo Prat and the Brazilian musician Heitor Villa-Lobos would present it.

The referred work of Aguado contributed to the emergence of another publication entitled $L a$ Nueva Tecnica de la Guitarra para la Practica de los Cincos Dedos de la Mano Derecha, by Domingo Prat (1886-1944). Prat suggested a radical change in the position of the right hand, which probably caused little acceptance among guitarists. Arm pulse severely bended and the inversion in the fingers order were opposite to tradition. The thumb, index, middle, ring and little fingers, played respectively the fifth, first, second, third and fourth strings (POSTWATE, 2001, p.7).

In Brazil, the composer Heitor Villa-Lobos (1887 - 1959) also referred to the use of the little finger in many parts of his classical guitar pieces. Chords and five notes arpeggios are present in many passages, which can serve as a challenge to demonstrate the effectiveness of using the fifth finger. Perhaps, due to that, some of his works were considered "not proper for classical guitar" by one of the great masters of the instrument, the Spaniard Andrés Segovia. PAES (2004, p.74) describes this fact in the narrative of a dialogue happened between the two musicians, Segovia and Villa-Lobos, in the version of the latter.

In his work entitled Right-Hand Studies for Five Fingers, POSTLEWATE (2001, p.8) clearly sets out the proposal and the results of the use of little finger. The same adds that, "(...) guitarists in recent years have begun using a right hand position that is straight from arm to the knuckles, as opposed to a wrist slightly bent to the right. This (...) makes the use of the little finger more accessible to the guitarists", and he continues:

\footnotetext{
"(...) One argument that guitarists have raised over the years has been the shortness of the right hand little finger, although, it has not kept them from using the equally short little finger of the left hand! (...) In the near future, guitarists will find it difficult to imagine not using the right hand little finger in the same manner that guitarists today would find it difficult to imagine a technique that excludes the ring finger (...)" (POSTLEWATE, 2001, p.8-9).
} 


\title{
3 - Hybrid picking applied to classical guitar
}

The guitar may be played in three ways in respect to the right-hand technique: the use of fingers exclusively, the use of the pick only and the use of both. The latter, called hybrid picking refers to the simultaneous use of pick and fingers.

\begin{abstract}
“(...) A general rule of hybrid picking is: low notes are hit with the pick (held with the thumb and index finger) and higher pitches are hit with any combination of your right middle (m), ring (a) and pinky fingers. Hybrid picking works equally well for both rhythm and lead play (...)" (FORMADLEY, 2003, p.1).
\end{abstract}

According to GOLD (2004, p.104), Cheney often plays "the country guitar technique known as hybrid picking, in which both the pick and fingers are used to sound riffs and melodies". Also, ASSIS-BRASIL (2005, p.5) refers many musicians who play the guitar of diverse musical genres applying this technique, such as "Brett Garsed, Carl Verheyen, Danny Gatton, Shawn Lane, Wayne Krantz, Steve Trovato, Albert Lee and Jerry Donahue". We can add to this list the names of Todd Kreuzburg, Joel Xavier, Jorge Martinez, Juan Pablo Ferrero and Victor Biglione.

Hybrid picking can be a solution for the limitations of using pick only, such as:

\begin{abstract}
“(...) playing two or more independent melodies at the same time (...). Some wide intervals are hard to play, especially when they have notes that skip strings. (...) polyphonic music situations like counterpoint, melody with bass lines, harmonized scales or sequences, walking bass lines with chords on top, classical guitar pieces and much more, (...)" (ASSISBRASIL, 2005, p. 5).
\end{abstract}

Besides the musical possibilities referred, some aspects relating to the pick deserve special attention, concerning the quality of the sound, such as size, shape and thickness; and also the type of material, the color and texture of the artifact. Some implications can arise from the choice of a particular type of pick, as often, some noise may be generated by the contact of it with the strings. This should be taken into account, because depending on the type of raw material used, it will have more or less influence on the sound result.

The basic picking movements are perpendicular in relation to the strings and directed upwards or downwards. The downstroke is effective in many rhythmic and harmonic bases such as in swing and gypsy jazz, blues, rock, heavy metal and in Brazilian forró and axé music. The upstroke can be easily found in the rhythmic-harmonic base of the Jamaican reggae. Alternate picking is the result of opposite movements of the pick, downwards an upwards, allowing to play fast melodic themes such as in Brazilian frevo and gaining fluency in melodic improvisations. Songs like "Um a Zero" and "Segura Ele" by Pixinguinha become feasible with hybrid picking.

The notation used in hybrid picking for indicating the picking movements are represented in figures 3 and 4: 


\section{П}

Figure 3: Downstroke (ASSIS-BRASIL, 2005).<smiles>CC(C)C</smiles>

Figure 4: Upstroke (ASSIS-BRASIL, 2005).

In hybrid picking, as the right hand index finger holds the pick along with the thumb, it is prevented from participating in usual guitar fingering. However, the lack of the index finger in this action is substituted by the use of the little finger, as it comes to maintain a corresponding profile to the traditional classical guitar technique (Figure 5).

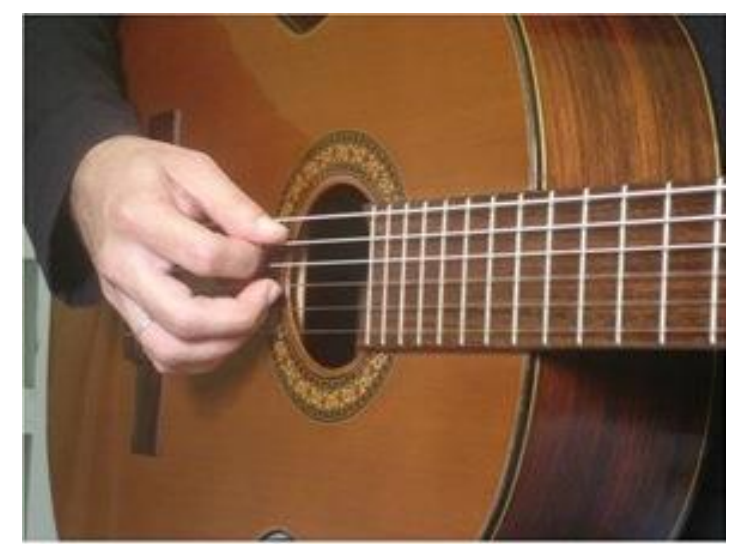

Figure 5: Right-hand positioning for the use of hybrid picking (Source: Personal Archive).

The nail size and shape of right-hand middle finger, ring and little, are also personal choices, as every guitarist has a particular hand anatomy. "The reason we play with our finger nails at all is to assist us in securing and controlling the string to enhance our volume and tone. So it is important that you grow and shape them in a way that will make it easier to play and sound good" (TENNANT, 1995, p.30).

Following are some examples of the application of hybrid picking for classical guitar. It begins with the movements of a pick (Figures 6-9).

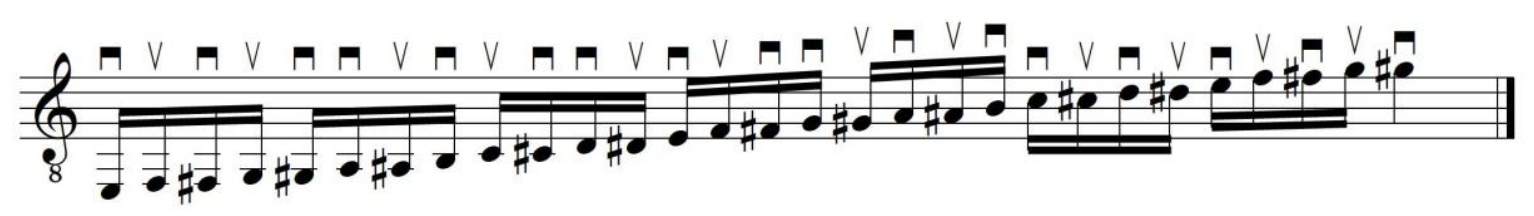

Figure 6: Ascending chromatic scale with alternate and sweep picking techniques. 

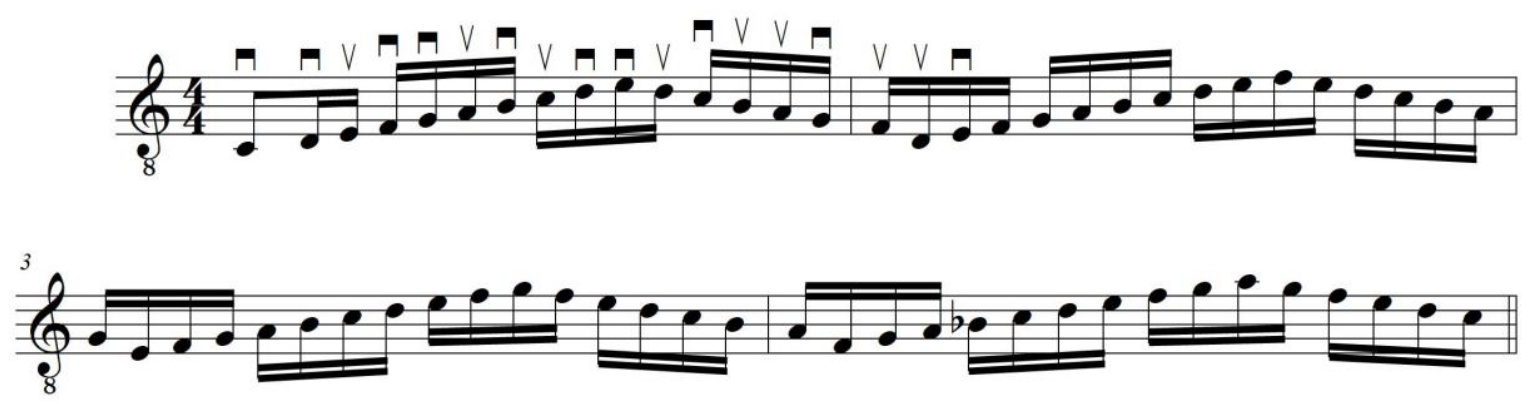

Figure 7: Study No. 4, op. 48 by Mauro Giuliani showing the application of alternate and sweep picking.

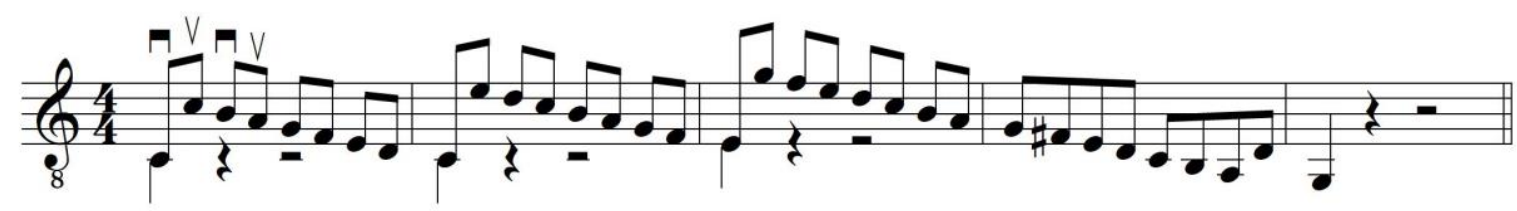

Figure 8: Study No. 1, op. 6 by Matteo Carcassi with alternate picking.
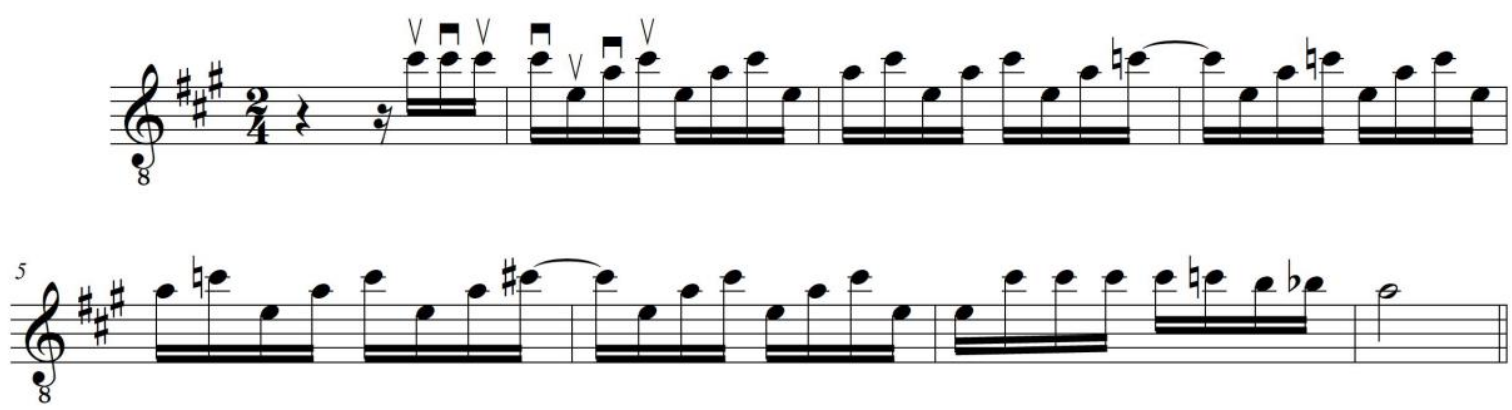

Figure 9: Brasileirinho by Waldir Azevedo with alternate picking.

Another possibility for the use of alternate picking is in the practice of repetitive patterns of right-hand arpeggios on classical guitar (Figure 10), as well as in broken chords, which are types of arpeggios with chord notes in a cascading effect (Figure 11). However, to perform these arpeggios, one can associate both alternate and sweep picking that is a special way of attacking adjacent strings in a same direction, as if the pick was "sweeping" the strings. The following examples refer to these ways of using alternate picking:

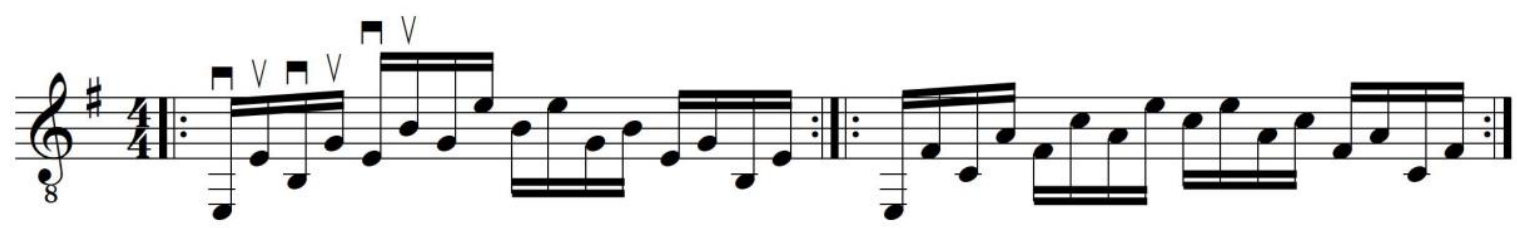

Figure 10: Study No. 1 by Heitor Villa-Lobos with alternate picking. 


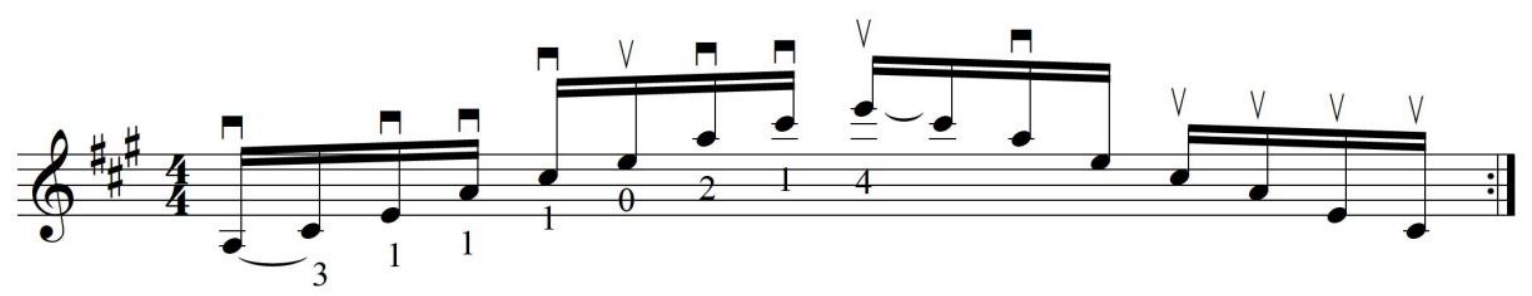

Figure 11: Study No. 2 by Heitor Villa-Lobos with sweep picking.

In order to apply hybrid picking, the musician who plays the guitar with the pick exclusively will have to develop the associated use of the fingers. Otherwise, the musician who plays the guitar with fingers only, and who wants to develop the use of the pick, will have to meet and implement the features and possibilities of this accessory. This is, at the same time, the biggest challenge that hybrid picking requires from guitarists and its greatest benefit for them: the possibility of using three ways to perform the instrument - the use of the pick, of fingers and both.

As this work focuses on the development of the practice of hybrid picking applied to classical guitar, the first rudiments of this technique can start by performing pieces with concurrent sounds. The joint attack of musical sounds of a chord allows observing the correct right-hand position and the sound quality, in accordance to the placement of the pick and of middle finger (m), ring (a) and little (c) (Figure 12).

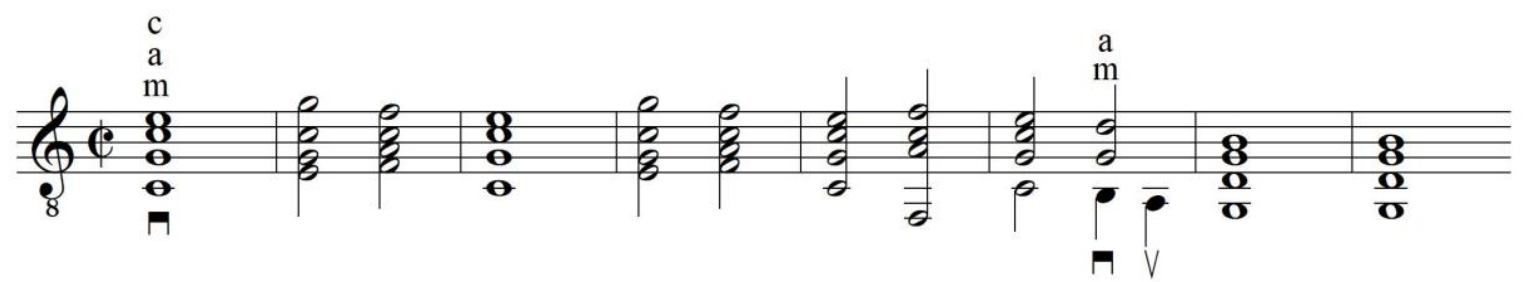

Figure 12: Pavan by Luys Milan, as an example of playing more than one note simultaneously.

Chord studies also serve as an example for the use of hybrid picking in the harmonic context (Figura.13):

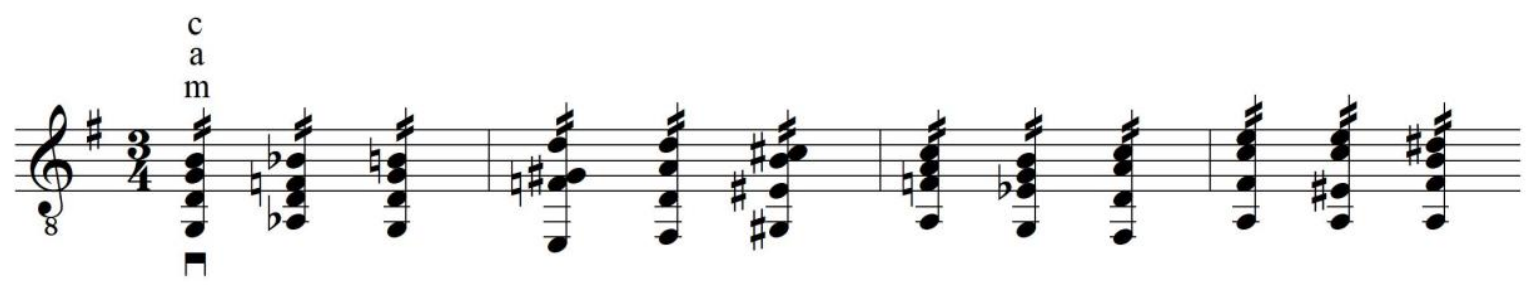

Figure 13: Study No. 4 by Heitor Villa-Lobos applying hybrid picking for repeated chords.

Right-hand arpeggios are present in many compositions for guitar. Such arpeggios play an important role for the development of right-hand technique in hybrid picking. In general, these parts contain a harmonic progression driven by the left hand and serve as a support for the 
performer's study, in addition to being indispensable for the development of motor coordination between pick and fingers (Figures 14 and 15).

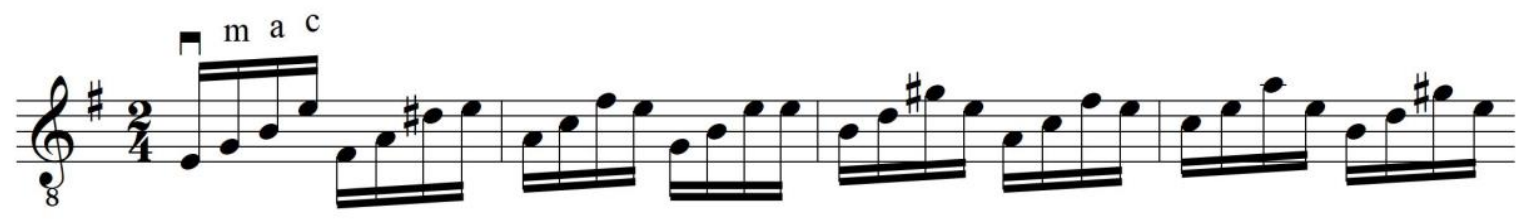

Figure 14: Prelude No. 4 by Heitor Villa-Lobos (excerpt), wich is suitable for training arpeggios with hybrid picking.

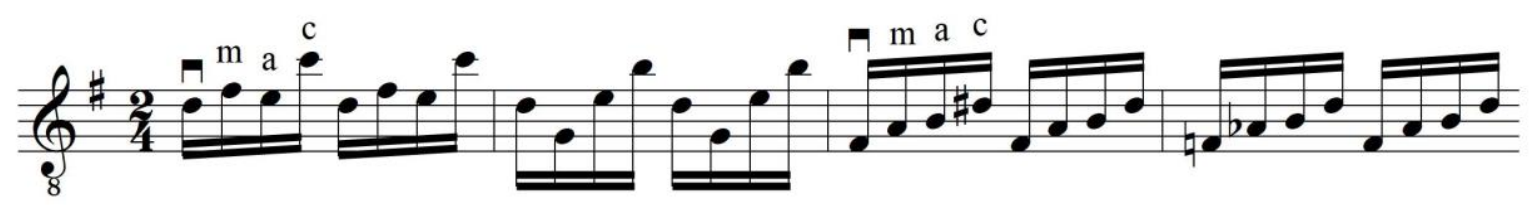

Figure 15: Brasileirinho by Joao Pernambuco is also indicated for playing arpeggios with hybrid picking.

For more extent arpeggios, usually, the pick hits more than one string with sweep or alternate picking. When these go beyond the four-note limit, exceeding the possibilities of non-repetition of pick and fingers, extra fingering solutions are necessary for playing any pattern (Figures 1618).

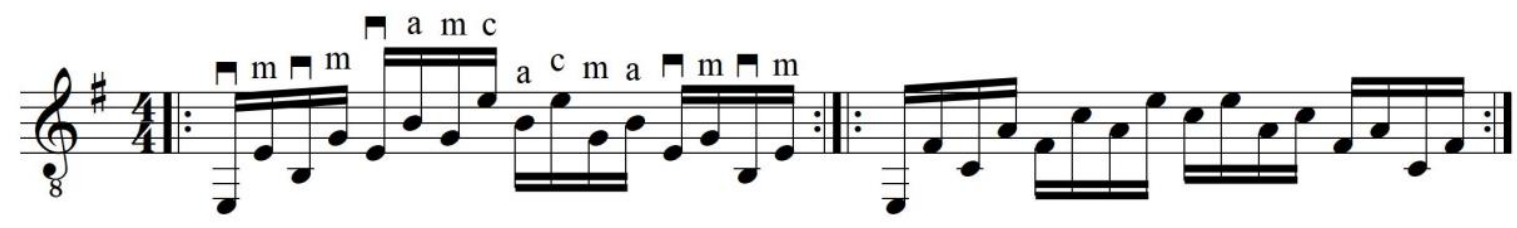

Figure 16: Study No. 1 by Heitor Villa-Lobos indicating the extra picking and fingering.

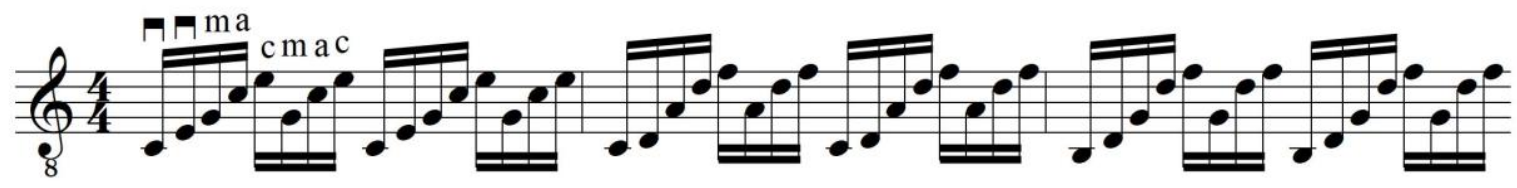

Figure 17: Well-Tempered Clavier Prelude No. 1 by J. S. Bach showing extent arpeggios with hybrid picking.

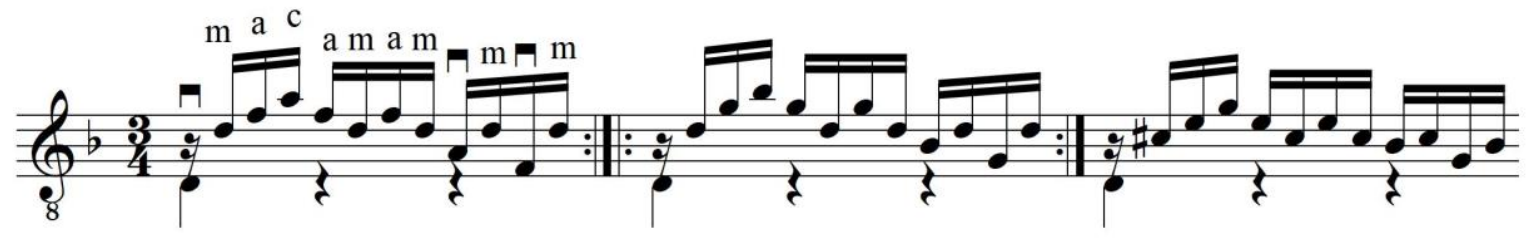

Figure 18: Prelude in D minor by J. S. Bach applying also more pick and fingers patterns in hybrid picking. 
In polyphonic music for two or more voices, hybrid picking is useful for playing simultaneous lines (Figure 19).

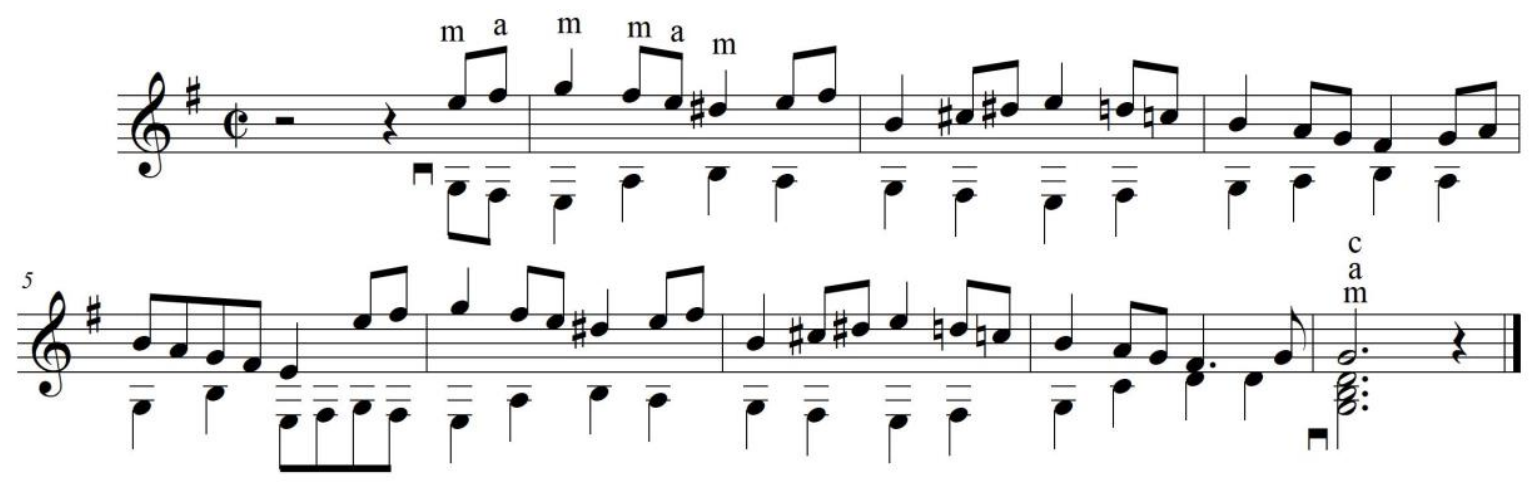

Figure 19: Bourrée from BWV 996 Lute Suite by J. S. Bach applying hybrid picking on two simultaneous lines.

Some bass lines combined with harmonic progressions are a very common practice in American jazz called walking bass. This can be performed on guitar with hybrid picking; the bass notes played with the pick and the chords with the fingers $\mathrm{m}$ - a - c. Following, there is a blues progression with walking bass line (Figure 20).
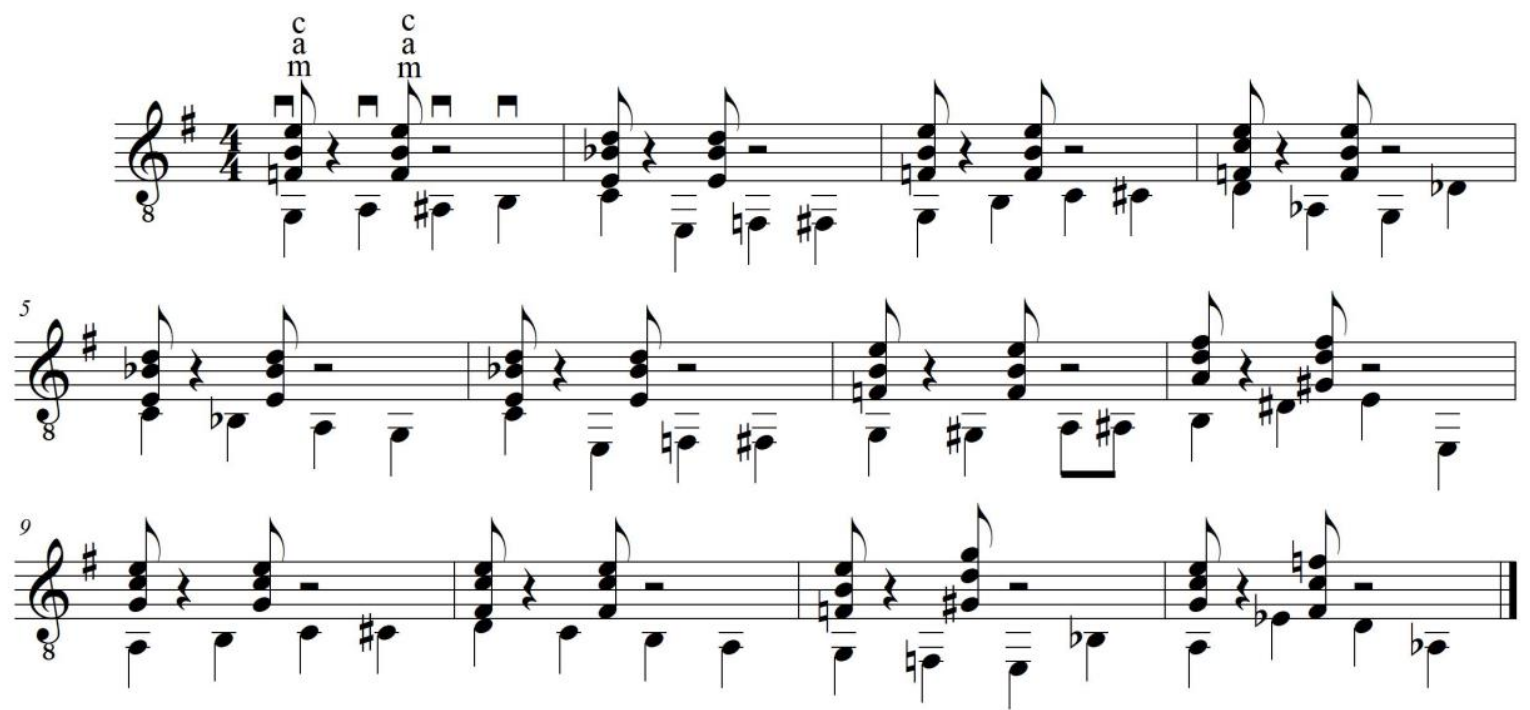

Figure 20: Harmonic blues progression with walking bass using hybrid picking.

Music with rhythmic-harmonic accompaniment perfectly meets the application of hybrid picking. The pick and right-hand fingers work in syncopated rhythm (Figure 21). 

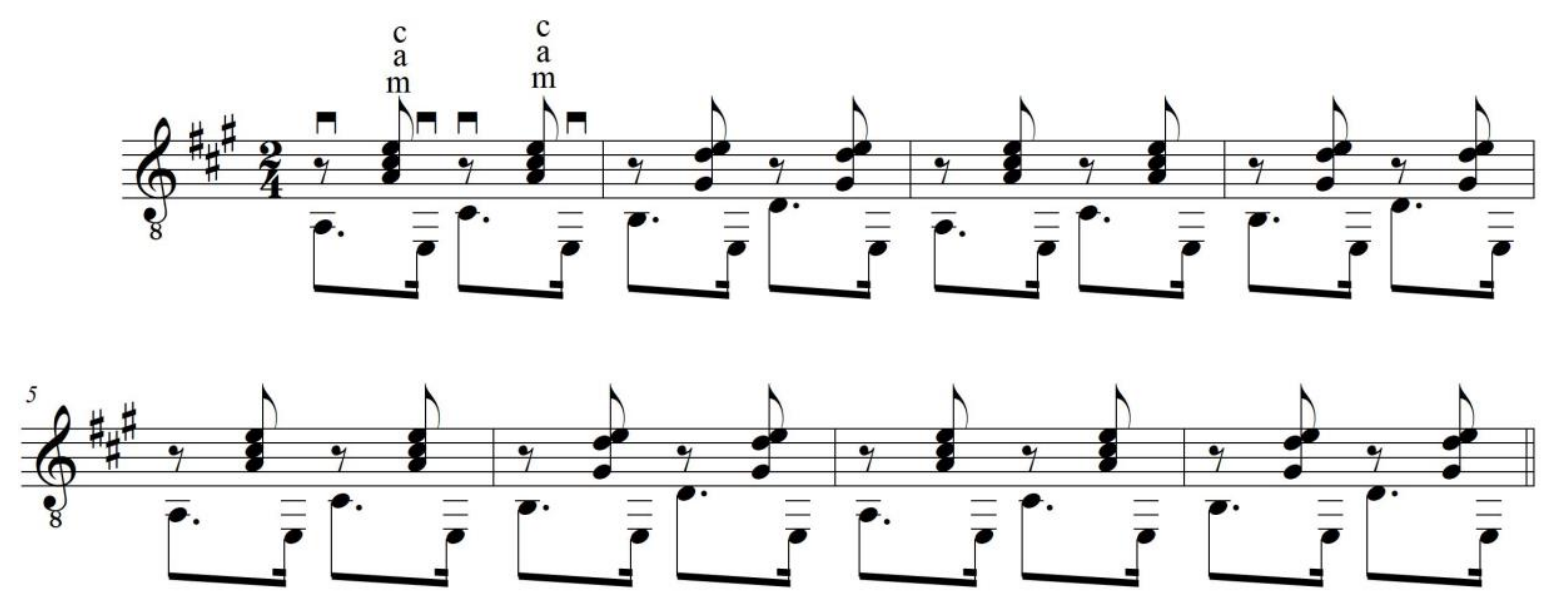

Figure 21: Brejeiro by Ernesto Nazareth showing a rhythmic-harmonic accompaniment with hybrid picking.

Another example combining bass lines, harmony and syncopated rhythm applied to hybrid picking can be seen in a bossa nova rhythm, like in the next excerpt from a composition of mine (Figure 22).
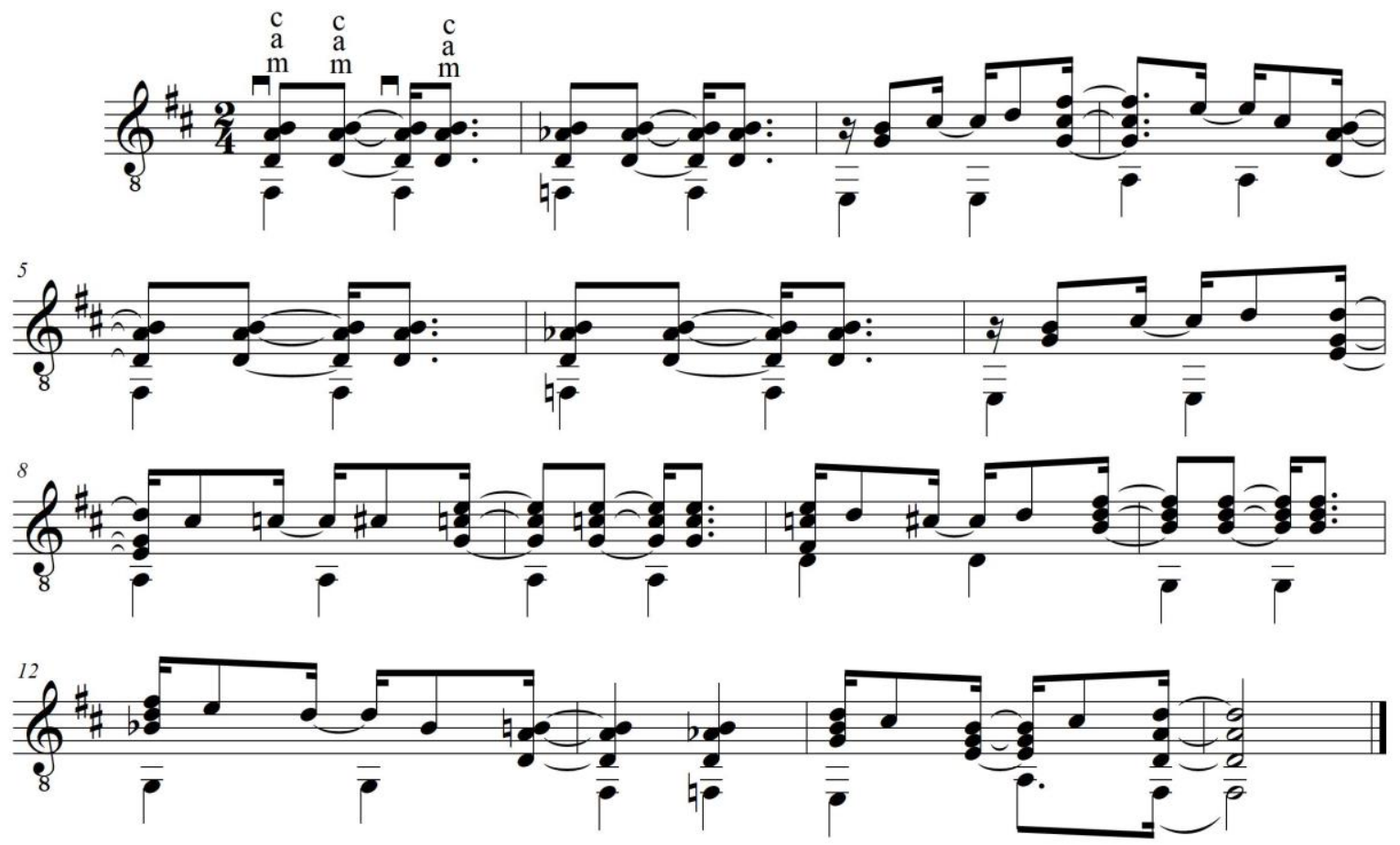

Figure 22: Bossa by Marcos Maia presenting hybrid picking with syncopated rhythms and bass line.

The next piece features the rhythm of Brazilian Northeastern baião. There is a continuous bass line, with the sixth string tuned in $\mathrm{D}$, in a repetitive rhythmic cell. The upper voice features melodic fragments, intervals and triads, thus, enabling to exercise the versatility of hybrid picking (Figure 23). 

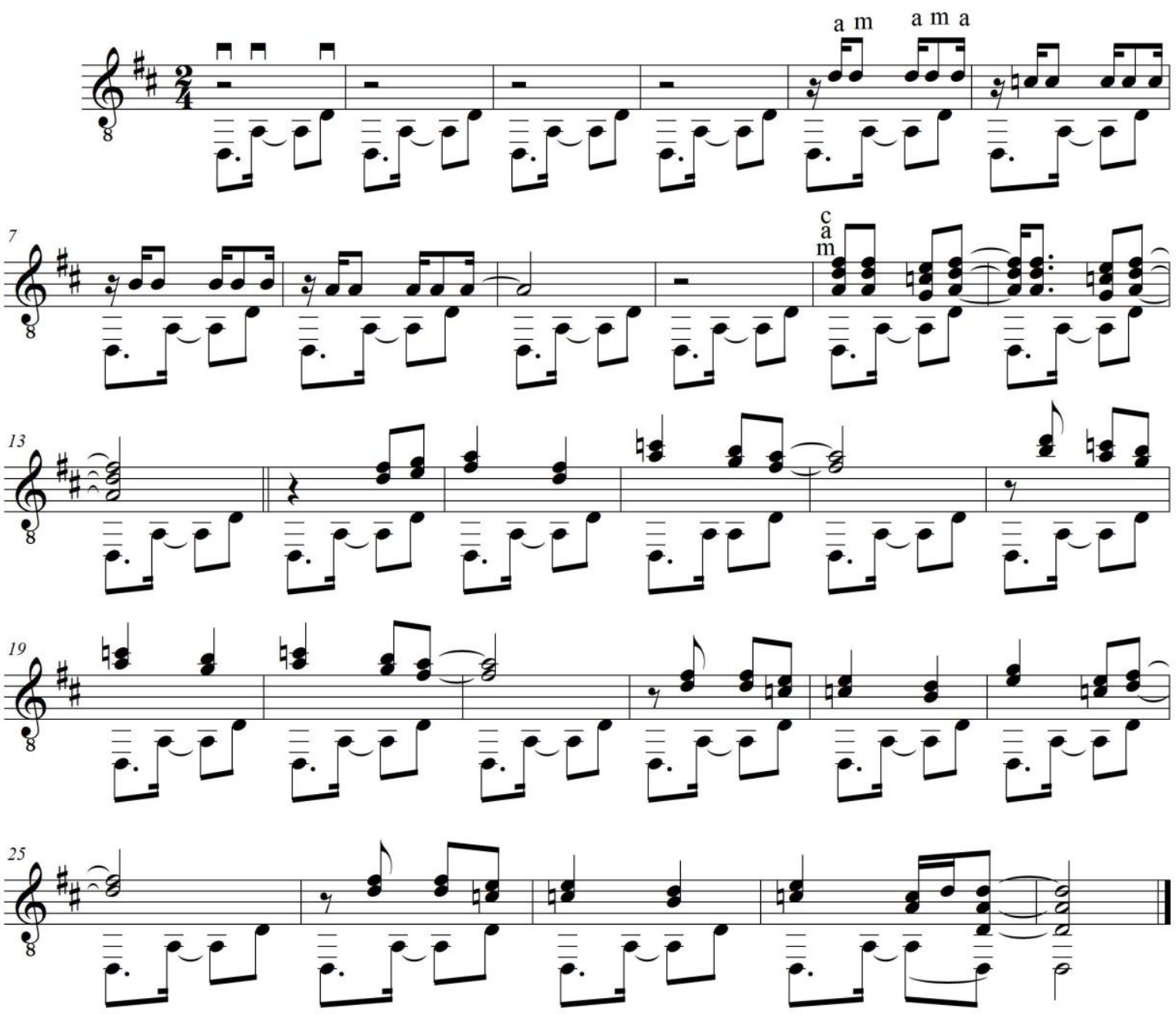

Figure 23: Baião by Marcos Maia showing the versatility of hybrid picking.

The examples shown demonstrate the possibility of using hybrid picking in music composed or arranged for classical guitar in various music styles and genres - melodic or harmonic solos, polyphonic or contrapuntal pieces - allowing melody, bass, harmony and rhythm to be carried out with speech clarity, thus providing technical development to guitarists. Melodies in fast tempo can be performed fluently with alternate picking; genres of rhythmic-harmonic character, requiring chord notes to be played simultaneously, are performed with use of pick and fingers.

\section{4 - Final considerations}

The research in guitar literature along historical periods showed that the use of the right hand little finger had already been proposed several times and that many guitarists served themselves of its effective use. The independence of the right hand fingers - middle, ring and little - can be developed even after the guitar player becomes mature, although the ideal is to be worked out at the guitarist initial phase of studies. Therefore, we recommend the early development and use of the right hand little finger. 
Hybrid picking applied to classical guitar associates the use of the pick and right-hand fingers aiming at reuniting these two features in performance, enabling the practice of transcriptions, arrangements or original compositions. The technique proposes a chance to expand the repertoire scope for those who use the pick exclusively, as it shown to be effective in its application to guitar performance, suggesting its inclusion in the curricula of guitarist training schools.

\section{References}

1. ASSIS-BRASIL, G. (2006). Hybrid Picking for Guitar. 2ed. Boston: Gustavo Assis-Brasil Music.

2. BIGGI, F. (1999). Half-serious considerations on a half-serious instrument: the medieval lute. Disponível em: <http://www.marincola.com/lutebot.html>. Acesso em: 10 de novembro de 2014.

3. CAMPOS, W. (2005). Uma Breve História do Violão. São Paulo: SESC.

4. FORMADLEY, C. (2014). Hybrid Picking Carrots and Grapes. Disponível em:

<http://www.guitar9.com/columnist207.html>. Acesso em: 10 de novembro de 2014.

5. GOLD, J. (2004). Thrash-a-Billy Boot Camp: Hybrid Picking Hijinks with the Living End's Chris Cheney. Guitar Player. n.7, v.38, p.104-109. August.

6. GRUNFELD, F. V. (1969). The Art and Times of the Guitar: an illustrated history of guitar and guitarists. New York: Da Capo Press.

7. HENRIQUE, L. (1988). Instrumentos Musicais. Lisboa: Fundação Calouste Gulbenkian.

8. HOOVER, W. (1995) Picks!: the colorful saga of vintage celluloid guitar plectrums. San Francisco, EUA: Miller Freeman Books.

9. HORTA, L. P. (1985). Dicionário de Música Zahar. Rio de Janeiro: Zahar.

10. PAES, E.A. (2004). Villa-Lobos e a Música Popular Brasileira: uma visão sem preconceito. Rio de Janeiro: Arte e Cultura Produções Ltda.

11. PINTO, H. (1978). Iniciação ao Violão: princípios básicos e elementares para principiantes. São Paulo: Ricordi.

12. PUJOL, E. (1960). El Dilema del Sonido en la Guitarra. Buenos Aires: Ricordi.

13. POSTLEWATE, C. (2001). Right-Hand Studies for Five Fingers. Missouri, EUA: Mel Bay.

14. TENNANT, S. (1995), Pumping Nylon: the classical guitarist's technique handbook. Baltimore, Maryland, EUA: Alfred Publishing Co.

15. TURNBULL, H. (1974). The Guitar: from the renaissance to the present day. New York, EUA: Charles Scribners's Sons.

Note about the authors

Marcos da Silva Maia holds a Master of Music from Unicamp. He graduated in Music Education License (UECE) and since 1988 he is a faculty member of that University, as Professor of Instrumental Practice - Guitar. He has performed professionally in many groups in the city of 
Fortaleza (CE) and as a guest soloist with several orchestras. In 1998, he launched his first CD - Ciclos - with his own compositions for guitar. He was one of those selected by Itaú Cultural for the project Musical Directions: trends and sheds (2000). He won the Best Original Score award at the 25th Guarnicê Film Festival (São Luís-MA), in June 2002. He has taught guitar workshops and was artistic and pedagogical coordinator of the Music Festival in Ibiapaba (Viçosa-CE) and also has performed and taught guitar in the Artistic Residencies of Jazz and Blues Festival (Guaramiranga-CE). At the moment, he is a student of the Doctorate of Music Program (Unicamp).

Carlos Fernando Fiorini holds a Doctor of Music (Conducting) and a Master of Arts (Music), both from Unicamp, and is graduated in Conducting and Composition at the same institution, in which, since 1998, he serves as Professor at the Conducting Department (Undergraduate and Postgraduate education). He worked as Assistant Conductor of the Symphony Orchestras of the State Universities of Londrina, of Sorocaba and of Bragança Paulista (SP). In 2000 and 2001 he served as Conductor and Musical Director of the Aldo Baldin Festival (Florianópolis-SC) and in assemblies of operas by Cia. Opera São Paulo. From 2005 to 2008 he was Assistant Conductor and, afterwards, Conductor of Municipal Symphony Orchestra of Campinas. He created, in 1996, the Camerata Anima Antiqua, a group dedicated to Renaissance music, of which he is Artistic Director. In 2009, he created at Unicamp Art Institute, an Internal Research Center dedicated to choir and orchestra conducting, so-called Conducting - Art and Technique, of which take part both the choir of Music Department and the Camerata Anima Antiqua. 